\title{
Investment Activity and Nature Conservation in Private Natura 2000 Sites in Poland - a Case Study
}

\author{
Jacek Witkowski* \\ Lublin University of Technology, Faculty of Management, Nadbystrzycka 38, 20-618 Lublin, Poland
}

Received: 5 November 2020

Accepted: December 2020

\begin{abstract}
The article deals with the problem of private investment and protection activities in Natura 2000 areas. In order to determine to what extent private owners are involved in conservation activities and whether the restrictions resulting from protective measures significantly affect the level of investment activity, a survey based on a questionnaire was carried out on a group of farmers with farms within which three areas of the European ecological network are located. It was found, inter alia, that owners rarely undertook investment projects on their farms in recent years, and those that were implemented very often were not subject to environmental impact assessment. The study also shows that the surveyed farmers on a smaller scale engaged in activities directly aimed at the protection of valuable ecosystems, despite the fact that they are obliged to do so by provisions in the plans of protective tasks. Some of the respondents would be willing to consider developing an additional, environmentally friendly service activity, but on condition that they receive appropriate support, especially in the form of tax preferences and training. The general conclusion that emerges from the study is that the functioning of new forms of nature protection does not have to stimulate more pro-ecological attitudes, and perhaps, in the absence of adequate environmental awareness, negatively affect economic and investment activity.
\end{abstract}

Keywords: Natura 2000, nature conservation, investment, farmer

\section{Introduction}

In the areas protected by the Natura 2000 program, there are various restrictions in use, and measures should be taken to protect naturally valuable species of flora and fauna. It is about both conservation activity and adapting everyday activities to predetermined requirements. The Natura 2000 program has been

*e-mail: j.witkowski@pollub.pl implemented in all European Union countries based on two legal acts, i.e. Directive 2009/147/EC of the European Parliament and of the Council of 30 November 2009 on the conservation of wild birds (previously Council Directive 79/409/EEC of April 2, 1979 on the conservation of wild birds) and Council Directive 92/43 / EEC of May 21, 1992 on the protection of natural habitats and wild fauna and flora. The first of these documents specifies the criteria for designating refuges for bird species threatened with extinction [1]. The second set out the rules for the protection of other animal species, as well as plants and natural 
habitats, and procedures for the protection of areas of special natural importance, obliging each Member State of the European Union to take measures to avoid the deterioration of habitats, inter alia, by implementing appropriate management plans [2]. Based on EU directives, two types of protected areas have been created in Europe, i.e. special protection areas for birds and special areas of habitat protection.

Taking care of the appropriate use of the areas of the European ecological network is very important in a situation where in each country of the Community they constitute a significant percentage of the total area, ranging from a dozen or so percent in most cases to over $30 \%$ in countries such as Slovenia, Slovakia, Croatia and Bulgaria [3]. Natura 2000 management plans are implemented in many Community countries. They formulate conservation objectives and determine how they will be managed, and regional and local governments, often in cooperation with site managers, users and other stakeholders, decide how these conservation objectives relate to land use and how to translate them into concrete measures [4]. The European Commission itself, when it comes to the structure and content of these plans, gives only a few guidelines, which in turn means that the planning approach is not rigid and conservative and is to lead to the gradual building of a territorial network based on an ecologically and economically sustainable approach. [5]. So far, however, no appropriate instruments have been developed to monitor compliance with the recommendations contained in management plans, and there are no wider use of economic instruments encouraging the implementation of projects enhancing the protective function of the areas of the European ecological network. Efforts to use financial instruments in this direction should be considered insufficient so far, and the current level of financing covers only a small part of the real needs [6]. All the more necessary is research on economic and investment activities conducted in the presence of environmentally valuable ecosystems. It is worth mentioning that, both in Poland and other countries, a considerable part of protected areas is in private hands

In Poland, where the share of Natura 2000 sites in the total area is about $19 \%$ and 849 habitat sites and 145 bird sites have been marked out [7], plans of conservation tasks (PZO) for Natura 2000 areas are developed and implemented. These plans define the protection goals, but also the activities subordinated to them, indicating the entities responsible for their implementation. However, in the case of private owners, these measures are largely optional. especially when the land user has decided not to participate in the so-called Agri-environmental Program and does not use subsidies in return for the implementation of protective measures provided for in the program. Unfortunately, in Polish conditions, the interest in this, in practice, the basic source of financing for nature protection in farms is still relatively small [8].
The aim of the study, the results of which will be discussed later in the paper, was to determine the scale of investment activity in private-owned Natura 2000 protected areas, as well as the level of involvement of the owners of these areas in the active protection of natural values. The case study covers the activity of a group of farmers living in the central-eastern part of Poland and owning land protected by the Natura 2000 program. In order to achieve the goal, an attempt was made to answer the following questions:

- whether farm owners are investing in protected areas and in their vicinity, and how they view the existing restrictions in this context?

- does the presence of Natura 2000 sites encourage farmers to take actions directly aimed at nature protection?

- would the owners be willing to develop additional environmentally friendly non-agricultural activities based on their resources and under what conditions?

\section{Research Method and Scope}

In the first half of 2019, a study was conducted using the survey questionnaire. The territorial scope of the study covered a part of the Masovian Voivodeship in central-eastern Poland, where three adjacent areas of the European ecological network Natura 2000 are located, i.e .: Special Protection Area for Birds "Middle Vistula Valley" (code: PLB140004); Special Protection Area for Birds „Ostoja Kozienicka” (code: PLB140013); Special Area of Habitat Protection „Puszcza Kozienicka” (code: PLH140035).

For all these areas, a plan of protective tasks has already been adopted and implemented, and each plan indicates, inter alia, protective measures for the implementation of which are the responsibility of private land owners or tenants (Table 1). This state of affairs in terms of security planning in Poland is still not the norm. Nationwide, such plans were established in mid-2017 only for slightly more than half of all Natura 2000 areas, and it is also known that for another 237 areas located in 12 different regions of Poland (voivodships), the plans will not be completed until the end of 2022 [9].

The questionnaire was addressed to 121 randomly selected people who own farms and deal only with agricultural activities. Within the boundaries of each farm there is at least one of the above-mentioned forms of nature protection. The form was completed by each of the target respondents personally and contained 28 closed questions. The individual points in which one or more options should be indicated from among the proposed answers concerned such matters as the creation and operation of legally protected facilities, pro-environmental activity on a farm with incentives to encourage such activity, investment activity and readiness to develop non-agricultural activities with respect for principles of sustainable development. 
Table 1. Selected protective measures listed in the plans of protection tasks for Natura 2000 sites located within the boundaries of the farms covered by the study.

\begin{tabular}{|c|c|}
\hline Natura 2000 Area & $\begin{array}{l}\text { Conservation actions specified in the plan of conservation tasks for which private owners or tenants are respon- } \\
\text { sible }\end{array}$ \\
\hline $\begin{array}{l}\text { Middle } \\
\text { Vall } \\
\text { (PLB14 }\end{array}$ & $\begin{array}{l}\text { - periodic fencing of bird breeding colonies and marking with information boards, during very low water levels } \\
\text { of the Vistula River, enabling free access to nesting sites, in order to limit the penetration of the area by people; } \\
\text { - isolation of the breeding colony from predators by using an "electric shepherd"; } \\
\text { - removal of bushes, mowing and felling of trees (omitting old trees) on overgrown sandy islands and meadows } \\
\text { with the removal of biomass within a specified period; } \\
\text { - preserving the habitat of the species that is the subject of protection through extensive mowing, mowing and } \\
\text { pasture or pasture use, grazing within a specified period, mowing the meadow within } \\
\text { a specified period. }\end{array}$ \\
\hline $\begin{array}{r}\text { Pus } \\
\text { Kozi } \\
\text { (PLH1 }\end{array}$ & $\begin{array}{l}\text { - maintaining the open nature of different types of habitats; } \\
\text { - maintaining extensive management of the meadows through use in accordance with the requirements of ap- } \\
\text { propriate agri-environmental packages and moderate cattle grazing; } \\
\text { - maintaining extensive management of the marsh meadows by mowing at a minimum height of } \\
10 \text { centimeters with swath removal (preferably by hand or light equipment), abandoning fertilization and use in } \\
\text { accordance with the requirements of appropriate agri-environmental packages; } \\
\text { - maintaining extensive management in fresh meadows by mowing a maximum of twice a year } \\
\text { (preferably by hand or light equipment), moderate cattle grazing, use in accordance with the requirements of } \\
\text { appropriate agri-environmental packages, abandoning the use of fertilization. }\end{array}$ \\
\hline $\begin{array}{l}\text { Ostoja Kozienicka } \\
\text { (PLB140013) }\end{array}$ & $\begin{array}{l}\text { - construction of 5-10 platforms for terns in water reservoirs; } \\
\text { - construction of special platforms for the black tern with their attachment; } \\
\text { - maintaining the open character of species' habitats through extensive use of meadow communities - mowing } \\
\text { in order to protect disappearing bird habitats (specifying the date and methods of mowing); } \\
\text { - limiting nitrogen fertilization and liming. }\end{array}$ \\
\hline
\end{tabular}

Source: [7-9].

\section{Research Results}

The first of the main research threads was the issue of readiness to take actions to protect the natural values located on the farm. Such involvement may be justified not only in the Natura 2000 area, but also in the areas directly adjacent to it. Among the activities contributing to the protection of natural resources, the respondents most often indicated the application of the Code of Good Agricultural Practice (91\% of responses) and the measures outlined in the protection plans $(52 \%)$, while occasionally indicated other options (Table 2). When it comes to creating new forms of protection, $8 \%$ of owners applied once in the last 10 years for the establishment of a new legally protected facility, although, as the answers show, on the farms there are usually no small forms, i. e. ecological uses and natural monuments. Slightly more than half of the owners $(55 \%)$ believed that the incentive to increase their involvement in protective measures could be tax reliefs and exemptions, including local taxes (on real estate, on means of transport, agriculture and forestry). A smaller group, however, attributed importance to the compensation due for restricting activities in protected areas (15\%).

Table 2. Actions supporting the protection of Natura 2000 areas undertaken by farm owners.

\begin{tabular}{|c|c|}
\hline Action & Percentage of respondents \\
\hline Application of the Code of Good Agricultural Practice & $91 \%$ \\
\hline Activities resulting from participation in the Agro-environmental Program & $6 \%$ \\
\hline Protective measures specified in the PZO & $52 \%$ \\
\hline Production of articles with a certificate of organic farming & $3 \%$ \\
\hline Periodic decommissioning of land for protective purposes & $2 \%$ \\
\hline $\begin{array}{l}\text { Construction of infrastructure elements for nature protection on the farm (e.g. birdwatching } \\
\text { viewpoints, educational paths) }\end{array}$ & $4 \%$ \\
\hline Protection activities outside the Natura 2000 areas & $2 \%$ \\
\hline
\end{tabular}

Source: Own study 


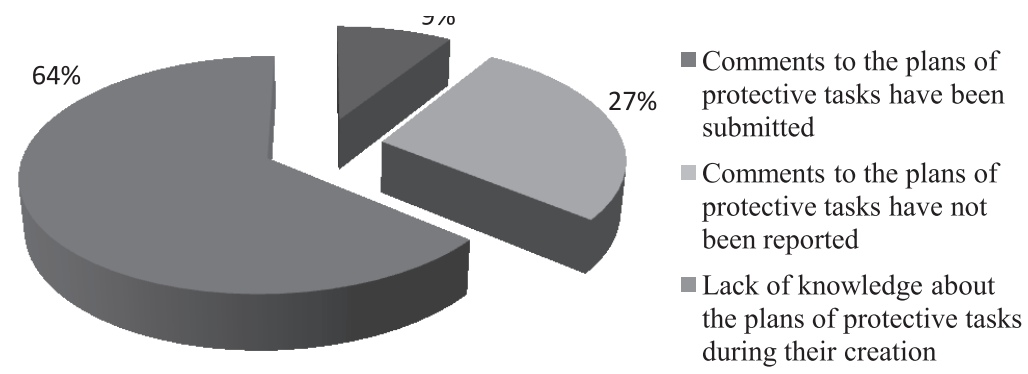

Fig. 1. Knowledge of the content of plans for the protection tasks of Natura 2000 areas and the frequency of submitting comments to these plans. Source: Own study.

The subject of the study was also the issue of farmers' participation in the process of creating plans for conservation tasks. In the case under consideration, these documents entered into force relatively long ago (all of them were adopted by 2016), and their content is widely available. In the questionnaire, it was considered justified to ask about the fact of submitting comments during the conducted public consultations, and thus about the knowledge of the proposed conservation objectives and activities subordinated to them in the planning phase. Out of the total number of respondents, slightly less than one in ten submitted comments, and another group of respondents $(27 \%$ of the sample size), knowing the proposals included in the PZO projects, consciously did not express their opinion. The remaining people declared no information on the plans at the time of their creation (Fig. 1).

All persons participating in the study use natural areas for economic purposes, declaring in most cases sufficient knowledge about the permitted uses, although on the other hand, a significant number of owners $(63 \%)$ believe that the applicable environmental and nature protection regulations are not specific and unambiguous. When it comes to the level of impediments to investment activity resulting from the necessity to respect the protective rigors, almost half of the respondents consider it moderate, and about one third as low or even do not see the related difficulties (Fig. 2). Every tenth farmer admitted that he often has doubts when making decisions on the farm due to the presence of forms of protection.

As for the investment activity of the surveyed farm owners, it shows a low level. Its indicator is the number of applications for a decision on environmental conditions for the implementation of a given investment project (environmental decision). In the case of farms, such a requirement applies in Poland, for example, to planned rearing or breeding of animals or construction investments. Conducting this type of projects may additionally be conditioned by a positive environmental impact assessment [13, 14]. In the discussed research sample, only $10 \%$ of people have submitted relevant documents necessary to obtain an environmental decision more than once in the last 10 years, and another $33 \%$ - once. In $5 \%$ of farms, an environmental impact assessment was carried out, which, taking into account the applicable law, must mean that the vast majority of projects were implemented in the vicinity of protected areas, not within them.

Farmers completing the questionnaire were also asked to answer a few questions regarding possible nonagricultural activities in the form of providing services in an environmentally friendly form of tourism, i.e. ecotourism (at the time of the survey, all respondents were only involved in typical agricultural activities). One in four of the survey participants would be willing to consider this type of new, additional business activity. In one of the points, it was asked to indicate the forms of expected support in the case of developing service activities. As in the case of incentives encouraging greater involvement in protective measures, the respondents most often indicated tax and other charges reliefs $(54 \%)$, followed by the organization of training courses to raise qualifications (40\%), promotional and marketing activities at the commune level $(24 \%)$ and assistance in initiating cooperation with other entities engaged in similar activities (12\%). However, no further initiatives increasing the level of protection of local natural values have been indicated. The above responses partly correspond with others, in which farm owners chose the factors most hindering, in their

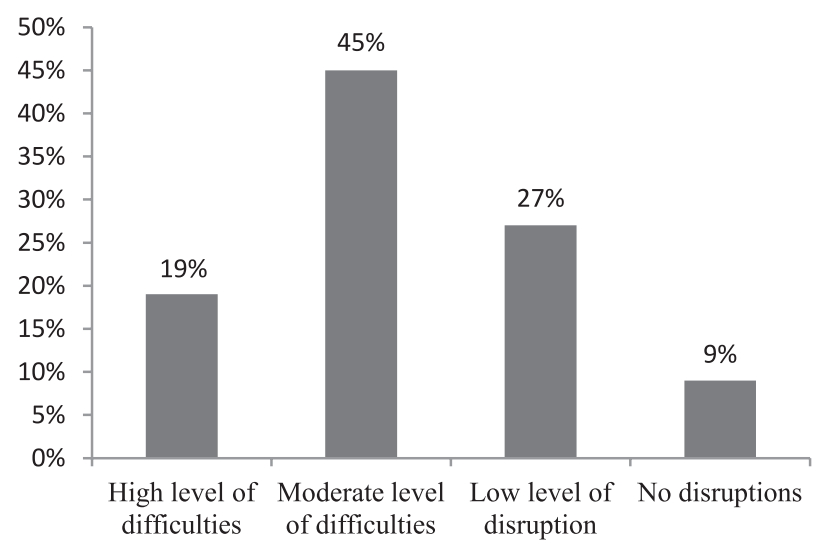

Fig. 2. The level of impediments to everyday economic activity resulting from the necessity to comply with the principles of nature protection. Source: Own study. 


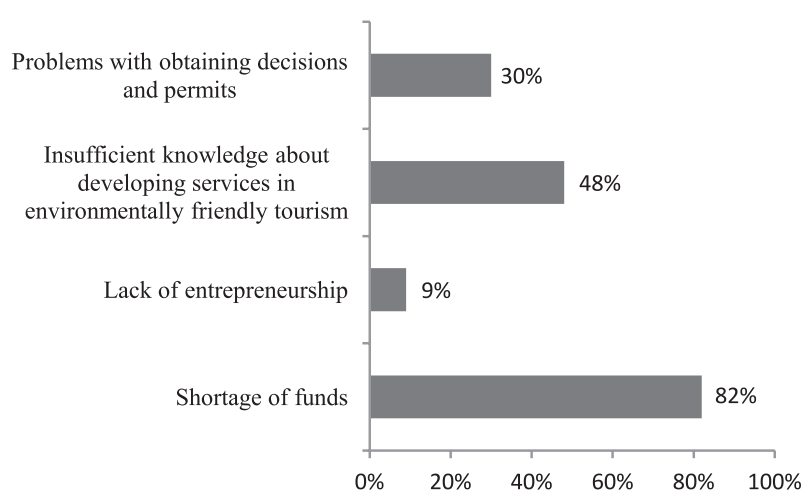

Fig. 3. Factors most hindering the development of additional service activities. Source: Own study.

opinion, the development of additional activities outside agriculture (Fig. 3). The first place was definitely the shortage of financial resources, which was indicated by $82 \%$ of the respondents. The options referring to insufficient knowledge about the provision of services in tourism based on the pro-ecological use of valuable natural resources ( $48 \%$ of indications) and difficulties in obtaining necessary decisions and permits $(30 \%$ of indications) were marked less frequently. Only a few of the respondents would see the problem of their lack of entrepreneurship ( $9 \%$ of people).

\section{Discussion}

The results of the study indicate the existence of certain problems that may negatively affect the sustainable development of protected areas. On the one hand, the farm owners who participated in the study are not willing to engage in more sophisticated forms of conservation activity, on the other hand, they seem to avoid the implementation of investment projects and related procedures, perhaps fearing a potential conflict between economic activities and nature conservation. Such conflicts have been reported from many European countries, often in the early stages of Natura 2000 implementation [15-20].

The surveyed persons use protected zones for economic purposes, and at the same time at least some of them do not take protective measures, despite the fact that such activities are required by existing protection plans. Such behavior of private owners of protected areas is also observed in other parts of Poland, which may indicate an insufficient level of ecological awareness. For example, a similar passivity in the area of initiatives for nature and environmental protection was found a few years ago in a study conducted in the Podlaskie Voivodeship, known for its rich biodiversity [21]. Some respondents pointed to the unclear nature of the current regulations relating to investments in protected areas, which may translate into low investment activity. A relatively small number of investment projects may also result from the way these regulations are perceived, which only a minority of farmers considered as a factor which generally does not interfere with the implementation of new projects. The lack of participation of a large percentage of respondents in the process of creating plans for protective tasks did not help in understanding the protective rigors and deepening the knowledge on how to take them into account in everyday activities. Such active participation in the work on the final shape is important both in the preparation of more broadly understood development plans [22] and documents relating more specifically to protected areas and methods of their management. [23-25]. In relation to the Natura 2000 program, this is particularly important because the process of delimiting protected areas took place without the participation of local communities and various stakeholder groups, and only at a later stage, when, among others, management tools for these zones are designed, it is possible to compensate for this exclusion, depending on solutions adopted in individual Member States of the Community [26]. Participation in public consultations may additionally become an opportunity to establish cooperation with other private entities managing the forms of protection. This cooperation could in the future contribute to increasing the propensity of private owners to pro-environmental behavior in a situation where they previously jointly negotiated the conditions for the development of protected areas owned by them [27]. However, most of the farmers participating in the study did not receive information about the meetings, thus they were not able to express their opinion, but also, perhaps, to obtain relevant knowledge that would allow them to look differently at the possibilities offered by the presence of protected natural values. Lack of this awareness and the belief that restrictions bring only losses, not benefits, may lead to a generally negative perception of protected areas and subsequent potential conflicts, which may also increase the costs of the protection itself and reduce its effectiveness [28, 29].

In order to preserve unique specimens of fauna and flora in Natura 2000 areas, it is necessary to conduct environmental impact assessments. It is surprising that in the analyzed farms this procedure was used so rarely over the decade, which of course cannot be explained solely by the fact that activities were located outside natural areas. In accordance with the European Union guidelines contained in the relevant directives, when assessing the potential effects of investment implementation, one should also take into account the indirect impact from the outside [30]. The reason for the low frequency of evaluation activities may be, on the one hand, the nature of the undertaken projects, and, on the other hand, the excessive restraint of the local government in referring the submitted projects to the assessment of the decision-making body competent to resolve matters related to activities in Natura 2000 areas (regional director of environmental protection). 
In Polish conditions, such a possibility is provided for in the Act of October 3, 2008 (Article 96) in a situation where the commune head decides that the planned activities, despite being located outside the protected area, may have a negative impact on this area. [13].

The study shows that farm owners would be willing to consider increasing their involvement in conservation activities and the environmentally friendly use of natural resources if they received greater support in the form of tax preferences. It is not only about taxes administered by the central government, but also about levies, the amount of which depends on the entities managing at the lowest local government level. In the fiscal systems of various European Union countries, and thus in the area of impact of the Natura 2000 program, there are opportunities to re-orientate local tax reliefs in such a way that they serve the purposes of nature protection [31]. The real estate tax, which is imposed at the local level both in Poland and in other EU countries, has a particularly large potential, often constituting the main tax base for local governments [32, 33]. In Poland, municipal councils have the right to grant real estate tax exemptions [34] and so far they have used this power relatively most often compared to other taxes they manage [33]. In the case of compensation for restrictions in the use of land, the results obtained, illustrating the approach of private entities to this issue, are in some contrast to what is generally found in, for example, local authorities, which are rather interested in such transfers in return for introducing pro-protective solutions [35, 36].

Valuable ecosystems may constitute the basis for the development of tourist services, but in accordance with the concept of eco-development, their exploitation should respect the principles of nature protection. Supporting entrepreneurship in areas with high natural values should be treated as a priority of the sustainable development policy, and the development of the economic sphere in this way is a driving force for development in other spheres [37]. A particularly desirable form in this context would be ecotourism and agritourism, which can be promoted as an important conservation tool and a way to have a positive impact on the environment. At the same time, it has the potential to develop education in the field of biodiversity protection, and to improve the economic conditions of the hosts [38]. The role that the aforementioned types of tourism can play as part of a nature conservation strategy depends, however, on individual conservation and use regulations and conservation plans, and how these deal with the sharing of benefits and costs of environmental services between stakeholders [39]. Local governments should therefore cooperate with private owners, and the introduction of various solutions should take place on the basis of a partnership combining the involvement of private and public entities [40]. In particular, the field of environmental education and related training requires the participation of local authorities, both in terms of organization and finance. Various studies show that local officials are relatively willing to participate in this type of enterprise [37, 41]. From the point of view of the surveyed group, it is important, because a large part of respondents perceive as their own weakness insufficient knowledge about conducting service activities in environment-friendly tourism. Perhaps it also underlies the fact that, in general, much fewer farms in Poland invest in tourism than in other non-agricultural activities [42].

\section{Conclusion}

Running a business in areas protected by the Natura 2000 program is associated with certain limitations in the use of land. The protective function of these zones is strengthened by the involvement of their private owners in conservation activities, but there is a need to create a solid basis for this in the form of an appropriate information campaign and launching various economic incentives encouraging this type of activity. As the example of a group of owners of farms located within several protected areas in the central-eastern part of Poland shows, the functioning of new forms of protection does not have to activate the private sector for more sustainable management and greater care for valuable natural values. At the same time, the need for private entities to comply with protective requirements may somewhat hamper their economic and investment activity, especially if the environmental awareness of people farming on a daily basis in agricultural areas subject to the protection regime does not increase.

\section{Conflict of Interest}

The author declares no conflict of interest.

\section{References}

1. Directive 2009/147 / EC of the European Parliament and of the Council of 30 November 2009 on the conservation of wild birds (Official Journal of the European Union No L 20/7)

2. Council Directive $92 / 43$ /EEC of 21 May 1992 on the conservation of natural habitats and of wild fauna and flora (Official Journal of the European Communities No L 206/7).

3. European Environment Agency. Available online: https://www.eea.europa.eu/data-and-maps/daviz/eionet/ visualisations/bise/eu-biodiversity-factsheets/datavisualization-1\#tab-chart_1 (accessed on 23 December 2020).

4. BOUWMA I., BEUNEN, R., LIEFFERINK D. Natura 2000 management plans in France and the Netherlands; carrots, sticks, sermons and different problems. Journal for Nature Conservation, 46, 2018.

5. LEONE F., ZOPPI C. Conservation Measures and Loss of Ecosystem Services: A Study Concerning the Sardinian Natura 2000 Network. Sustainability, 8, 1061, 2016. 
6. GEITZENAUER M., BLONDET M., DE KONING J., FERRANTI F., SOTIROV M., WEISS G., WINKEL G. The challenge of financing the implementation of Natura 2000 -Empirical evidence from six European Union Member States. Forest Policy and Economics, 82, 4, 2017.

7. General Directorate for Environmental Protection. Available on: https://natura2000.gdos.gov.pl/natura-2000w-polsce. (accessed 23 December 2020) [In Polish].

8. GOTKIEWICZ W., KLIMECKI T. Proenvironment activities in agricultural holdings with the emphasis on agri-environmental programs, Annals of The Polish Association of Agricultural and Agribusiness Economist, 18 (5), 2016.

9. Implementation of the Birds Directive and the Habitats Directive. General Director of Environmental Protection. Warsaw 2017. Available online: https://www.senat.gov.pl/ gfx/senat/userfiles/_public/k9/komisje/2016/ks/materialy/ mat_1_73.pdf. (accessed on 06 October.2020) [In Polish].

10. Ordinance Regional Director of Environmental Protection in Warsaw and Regional Director of Environmental Protection in Lublin of 30 May 2016 amending the ordinance on the establishment of a plan of protective tasks for the Natura 2000 area Middle Vistula Valley PLB 140004 (Official Journal Mazovieckie Voivodeship 2016, item 5083) (Poland).

11. Order No.16 Regional Director of Environmental Protection in Warsaw of March 312014 on the establishment of a plan of protective tasks for the Natura 2000 area Puszcza Kozienicka PLH140035 (Official Journal Mazovieckie Voivodeship 2014, item 3829) (Poland).

12. Order No. 13 Regional Director of Environmental Protection in Warsaw of March 31, 2014 on the establishment of a plan of protective tasks for the Natura 2000 Ostoja Kozienicka area PLB140013 (Official Journal Mazovieckie Voivodeship 2014, item 3826) (Poland).

13. The Act of 3 October 2008 on providing information on the environment and its protection, public participation in environmental protection and on environmental impact assessments (Journal of Laws 2018, item 2081) (Poland).

14. Ordinance the Council of Ministers of 10 September 2019 on projects that may significantly affect the environment (Journal of Laws 2019, item 1839) (Poland)

15. GALLOA M., PEZDEVŠEK MALOVRHB Š., LAKTICĆ T., DE MEOA I., PALETTO A. Collaboration and conflicts between stakeholders in drafting the Natura 2000 Management Programme (2015-2020) in Slovenia. Journal for Nature Conservation, 46, 2018.

16. BEUNEN R. European Nature Conservation Legislation \& Spatial Planning: for Better or for Worse? Journal of Environmental Planning and Management, 49 (4), 2006.

17. BEUNEN R., VAN ASSCHE K., DUINEVELD M. Performing failure in conservation policy. The implementation of European Union directives in the Netherlands. Land Use Policy, 31 (1), 2013.

18. GAŁECKA-DROZDA A., RASZEJA E., SZCZEPAŃSKA M., WILKANIEC A. Land cover changes in Natura 2000 areas located in suburban zones: planning problems in the context of environmental protection. Polish Journal of Environmental Studies, 28 (2), 2019.

19. GOTKIEWICZ W., WIŚNIEWSKA A. Threats to biodiversity in Natura 2000 sites on the example of the Region of Warmia and Mazury. Environmental Protection and Natural Resources, Vol. 29, No 2 (76), 2018.

20. IZAKOVIČOVA Z., MIKLÔS L., MIKLÔSOVA V. Integrative Assessment of Land Use Conflicts. Sustainability, 10 (9), 3270, 2018.
21. KIRYLUK H. Pro-environmental behavior and the activity of local communities in the areas of tourism Deception of the Podlaskie Voivodeship. Europa Regionum, Vol. XXIV, 92, 2015.

22. ČIEGIS R., GINEITIENE D. Participatory aspects of strategic sustainable development planning in local communities: Experience of Lithuania. Technological and Economic Development of Economy, 14:2, 2008.

23. CENT J., KOBIERSKA H., GRODZIŃSKA-JURCZAK M., BELL S. Who is responsible for Natura 2000 in Poland? - a potential role of NGOs in establishing the programme. International Journal of Environment and Sustainable Development, 6, 2007.

24. HONGSLO E., HOVIK S., ZACHRISSON A., LUNDBERG A.K.A. Decentralization of conservation management in Norway and Sweden - different translations of an international trend. Society \& Natural Resources, Vol 29, 2016.

25. PRÖBSTL U. NATURA 2000 - The influence of the European directives on the development of nature-based sport and outdoor recreation in mountain areas. Journal for Nature Conservation, 11 (4), 2003.

26. LAI S. Hindrances to Effective Implementation of the Habitats Directive in Italy: Regional Differences in Designating Special Areas of Conservation. Sustainability, 12, 2335, 2020

27. HOFFMAN M. The role of public land use planning in facilitating conservation on private land. Natural Areas Journal, 37 (4), 562, 2017.

28. ALKAN H., KORKMAZ M., TOLUNAY A. Assessment of primary factors causing positive or negative local perceptions on protected areas. Journal of Environmental Engineering and Landscape Management, 17 (1), 2009.

29. WÄTZOLD F., MEWES M., VAN APELDOORN R., VARJOPURO R., CHMIELEWSKI T. J. VEENEKLAAS F., KOSOLA M-L. Cost-effectiveness of managing Natura 2000 sites: an exploratory study for Finland, Germany, the Netherlands and Poland. Biodiversity and Conservation, 19, 2065, 2010.

30. MÖCKEL S. The European ecological network "Natura 2000 " and the appropriate assessment for projects and plans under Article 6(3) of the Habitats Directive. Nature Conservation, 23, 21, 2017.

31. KETTUNEN M., ILlES A. (Eds.) Opportunities for innovative biodiversity financing: ecological fiscal transfers (EFT), tax reliefs, marketed products, and fees and charges. A compilation of cases studies developed in the context of a project for the European Commission (DG ENV) (Project ENV.B.3/ETU/2015/0014), Institute for European Policy (IEEP): Brussels / London, 2017.

32. European Commision. Possible reforms of real estate taxation: Criteria for successful policies. European Economy. Occasional Papers, 119, 23, 2012. Available online: http:// ec.europa.eu/economy_finance/publications (accessed on 29 November 2019).

33. PODSTAWKA M., RUDOWICZ E. Utilization for example local taxes in creating the fiscal policy of communes. European Policies,Finance and Marketing, 4 (53), 86, 2010 [In Polish].

34. ETEL L. Uchwały podatkowe samorządu terytorialnego; Temida 2: Białystok, 82, 2004 [In Polish].

35. SANTOS R., RING I., ANTUNES P., CLEMENTE P. Fiscal transfers for biodiversity conservation: The Portuguese Local Finances Law. UFZ Discussion Paper, No. 11, 21, 2010. 
36. GUZAL-DEC D. Samorząd gminny w kreowaniu zrównoważonego rozwoju obszarów przyrodniczo cennych województwa lubelskiego; Pope John Paul II State School of Higher Education in Biala Podlaska: Biała Podlaska, 349, 2015 [In Polish].

37. GUZAL-DEC D. Commune self-government in sustainable development of environmentally valuable areas. Economic and Regional Studies, 9 (3), 86, 2016.

38. MCKINNEY T. Ecotourism, [In:] The International Encyclopedia of Primatology; Fuentes, A., Ed.; John Wiley \& Sons, Inc., 1, 2016.

39. LEITIES E. The Role of Ecotourism in the Reduction of Anthropogenic Load on Natura 2000 Territories throughout Latvia. Scientific Journal of Riga Technical University, 7, 82, 2011.
40. GIOS G., GOIO I., NOTARO S., RAFFAELII R. The Value of Natural Resources for Tourism: a Case Study of the Italian Alps. International Journal of Tourism Research, 8, 84, 2006.

41. WITKOWSKI J. Forms of environmental education supported by local self-governments in Poland on the example of projects implemented in the Lubelski Region, ICERI Proceedings, Seville, 2016.

42. ZIOŁO M., JAWORSKA M. Multivariate statistical analysis of non-agricultural business activity of farmers in the European Union Member States. Europa Regionum, Vol. XXII, 137, 2015. 